\title{
PERSPECTIVES ON PLEA BARGAINING
}

\author{
MALCOLM M. FEELEY
}

\section{INTRODUCTION}

Plea bargaining is finally coming to be recognized for the important institution it is. There is a rapidly growing body of research that describes its variations, reports on its impact, and discusses its implications. Despite these advances, however, much of this literature is fragmented, anchored in separate disciplines, and often lacking in broad context and historical perspective. And although much of the empirical research on plea bargaining has a distinct reform orientation or offers important implications for reform, this is often implicit or presented in a way that is neither convincing nor useful to practitioners.

This symposium is designed to overcome some of these deficiencies by presenting papers that move beyond the narrow confines of discipline and perspective, and by allowing those who hold very different views to confront one another. Five broad sets of issues have given rise to the mix of papers presented in this symposium. They are: the social organization of the adjudication process-what plea bargaining is; the causes of plea bargaining; the consequences of plea bargaining; the legitimacy of plea bargaining; and proposals to eliminate, reform, or restructure plea bargaining.

\section{ISSUES IN RESEARCH ON PLEA BARGAINING}

Because it has come to explain so much, plea bargaining is in danger of explaining too little. Because the concept is so inclusive and refers to such a variety of practices, important differences, subtle variations, degrees of magnitude, and functional equivalents are in danger of being obscured. People plead guilty for a variety of reasons. Furthermore, as Mather's (1974) study reports, even a trial can come to be the functional equivalent of a plea bargaining session.

Plea bargaining - the explicit or implicit exchange of reductions in charge for a plea of guilty-must be understood in the context of the negotiations that permeate the criminal process. There is negotiation over sentence as distinct from charge, over dropping all charges as distinct from reducing them, over facts as distinct from the purely instrumental manipulation of 
charges (Rosett and Cressey, 1976; Utz, 1978); each can be implicit or explicit. There is horse-trading (Cole, 1970)-"give me a break on this case and I'll do the same on that case"-and there are "principled" negotiations (Eisenberg, 1976). There are the perfunctory pleas of guilty in traffic and lower courts, which involve trivial sanctions and minimal stigma; there are pleas of guilty in complex "white-collar" cases involving detailed negotiations over the "meaning" of the activity under question; and there are pleas of guilty in cases involving major crimes of violence. There are pleas of guilty in courtrooms spilling over with business and confronting crowded jails and lengthy dockets, and there are pleas of guilty in courtrooms in which a serious case and the prospects of a trial offer a welcome relief from the tedium of routine business and too little work. Each combination of case and circumstances is likely to call into play quite different considerations. To lump them all under the blanket phrase plea bargaining may conceal more than it reveals. If plea bargaining is the generic term for negotiation in the criminal process, then we need a richer vocabulary for generating typologies and exploring in greater detail the process of nontrial.

\section{THE CAUSES OF PLEA BARGAINING}

Much of the literature on plea bargaining implies that pleading guilty to criminal charges is somehow pathological, a deviation from the "natural" course of events in the criminal justice system (Blumberg, 1967). This perspective equates the adversary system with the trial, arguing that the two are so inextricably linked that when the latter is not present the former is subverted. Such a perspective then pursues an explanation for the practice of pleading guilty by searching for disruptions, "unnatural" situations in the criminal process that give rise to unnatural events, in much the way that a doctor searches for the cause of disease. The factors blamed have included the press of heavy caseloads, the oppressiveness of pretrial detention, the low quality of public defenders, the financial incentives of private attorneys, the laziness of prosecutors, and the stupidity of judges. But increasingly these explanations are coming under fire (Heumann, 1975; Feeley, 1975), and others are being suggested (Eisenstein and Jacob, 1977; Heumann, 1978). Mounting evidence indicates that pleading guilty for consideration has a longer history than is commonly supposed (Heumann, 1975; Wishingrad, 1974; Alschuler, infra; Friedman, infra. Legal historians are pointing out that flexibility has characterized the criminal process for years. 
This broader view suggests other factors to consider when constructing an explanation for plea bargaining-the rise of specialization and professionalism. During the early part of this century the handful of relatively simple criminal provisions was replaced by lengthy criminal codes that described in minute detail a lengthy catalogue of distinct criminal offenses. The latter invite challenge and negotiation. The rise of courthouse professionals has also contributed to the demise of trials and the rise of plea bargaining. The trial originated as an institution for amateurs, a public forum and a set of procedures for pursuing charges, offering defenses, and rendering verdicts. The jury played a major role. But as reliance on professionalism and improved technology have increased, the role of the amateur in the criminal process has decreased, and so has the frequency of trials. Ironically, the expanded use of defense counsel may have sounded the death knell for the trial in all but a few cases. A defendant who, lacking an attorney, might once have sat passively through a ritual trial is now likely to be represented by counsel capable of challenging evidence in a host of pretrial proceedings, who will resort to trial only if the client's interests cannot otherwise be secured. Similarly, prosecutors with larger and better trained staffs may spend more time scrutinizing cases, weeding out the weak ones, and adjusting charges early in the process. The effort to explore the basic elements of a case, which was previously expended at trial, can now be invested earlier and more efficiently. Thus as trials have decreased, pretrial activities appear to have increased, and as part-time amateurs have declined, full-time professionals have taken their place. If this perspective has any merit (see Friedman, infra), then plea bargaining may not be as opposed to adversariness as its critics maintain.

Although critics often charge that the rise of plea bargaining represents the triumph of administrative and organizational interests over justice, they overlook the fact that many charge reductions are made "in the interests of justice." The first person arrested and charged under the new Massachusetts law that mandates a minimum prison sentence of one year for conviction of illegal possession of a gun is said to have been a 70year-old woman fearful of being raped. No judge in America is likely to imprison such a defendant, and a charge reduction facilitates the pursuit of substantive justice in the face of legal inflexibility. The law is filled with such devices (fictions, equity) 
and plea adjustments are but one more device to facilitate similar ends. No doubt the Massachusetts story is fanciful; nevertheless, it illustrates a point all too often glossed over by "hardnosed" students of the criminal process, that substantive justice can be facilitated by flexibility in charging and pleading. If the findings of Utz (1978), Rosett and Cressey (1976), the Vera Institute (1977), and Feeley (1979) can be generalized, this is not an insubstantial function of plea bargaining.

\section{THE CONSEQUENCES OF PLEA BARGAINING}

What are the consequences of plea bargaining? Are vast numbers of innocent people being convicted (Finkelstein, 1975)? Serious crimes receiving light sentences? Is the sentencing system riddled with inconsistencies and invidious disparities? Are those who plead guilty the unwitting dupes of their attorneys or are they shrewd manipulators of a complex and chaotic system?

Unfortunately, we cannot answer these questions satisfactorily. The process of adjudication is an elaborate device for ascertaining truth and there is no instrument by which its accuracy can readily be measured. The obvious method-a controlled experiment-is constitutionally and morally repugnant under the circumstances. Thus we must resort to indirect indicators and subtle inferences. Of course, this approach is fraught with its own difficulties. There are far too few trials in relation to the number of guilty pleas to allow much confidence in a comparison of the sentences that follow each process. Even if cases were randomly assigned this ratio of roughly 1 to 9 would make inferences extremely hazardous. And actually the situation is far more complex because of the host of factors that channel cases into one or the other alternative.

Clearly someone is advantaged by guilty pleas; otherwise there would be none. The question for researchers is to determine what these advantages are, and who obtains them. Do they accrue to attorneys and courts interested in speed and efficiency at the expense of the accused? Do they benefit defendants as well? Existing studies suggest an affirmative answer to both of these questions. The task of future research is to chart more carefully these advantages and consequences. Given that random assignment of cases is impossible, perhaps some of these questions might fruitfully be pursued through simulations. 


\section{THE LEgITIMACY OF PLEA BARGaINING}

Despite much heated debate about the causes, consequences, and desirability of plea bargaining, the underlying normative issues have rarely been treated in systematic fashion. Strong statements pro or con are made without supporting arguments and writers view their positions as self-evident once the "facts" are established. Nevertheless, there are important and complex issues in need of philosophical analysis. How accurate must a fact finding system be to justify acceptance? What is the appropriate balance between the costs to society of refining procedures and the costs to the individual of allowing errors? At what point does inducement to waive rights become unacceptable coercion? Because the facts necessary to answer these questions will be difficult to obtain, it is important that we clarify the issues and adopt normative theories in order to focus empirical inquiry. A coherent policy on plea bargaining must ultimately be rooted in a theory of justice.

\section{PLEA BARGAINING REFORMS}

Concerns over the justness and propriety of plea bargaining have given rise to a host of reforms. Some have simply sought to "bring plea bargaining out into the open" in an effort to allay fears that its proponents regard as unfounded. Thus they may recommend that negotiations take place in the presence of a judge or in open court in order to lend an air of legitimacy to the process and protect not only the interests of justice but also the appearance of justice.

Other reforms reflect a more critical judgment of plea bargaining and are designed to affect the outcomes of cases as well as the way they are handled. Some want to involve the accused in the process so that they are not sold short by a busy or careless lawyer. Others, troubled by what they view as undue leniency, are critical of current practices that ignore the desires of the victim and the interests of the public. They advocate that the complainant and the arresting officer participate in negotiating sessions so that they can influence any settlement. Yet another group is concerned with sentencing disparity and wants the judge to preside over the negctiating session so as to limit it to "legally relevant" factors. Finally, there are proposals that would invalidate all guilty pleas influenced by implicit or explicit promises of leniency.

Given the difficulties inherent in measuring the consequences of plea bargaining, these proposals may be aimed at 
evils that are more imagined than real. In the absence of hard evidence, the occasional horror stories may acquire an exaggerated significance. Under such circumstances, evaluating the success of reforms is also problematic. Calls to abolish or reduce plea bargaining can easily become mere rhetorical ammunition for election campaigns; those proposals that are implemented can alter form but not substance. The criminal court is a complex hydraulic system, and pressure exerted at one point inevitably produces deformation at another.

I do not want to claim that efforts to alter the guilty plea process are foredoomed. I only wish to reiterate what students of mandatory and determinate sentencing schemes have long maintained: eliminating discretion at one stage of the process fosters it at others (Alschuler, 1978). Proscribing any postindictment modification of charges may simply result in increased pre-indictment "plea adjustment." Reforms that focus exclusively on a narrow problem without seeing it in the context of the entire system may generate unanticipated consequences even less desirable than the status quo.

But reforms may be aimed at something other than their manifest targets. Some campaigns by chief prosecutors against plea bargaining are intended less to eliminate the practice than to increase the accountability of their assistants, eliminate disparities within a large and unwieldy office, or weed out weak and ineffectual assistant prosecutors. Or it may be a strategy focused upon a selected group of cases in order to upgrade the "going rate" for those offenses. If the goals are more limited, the reforms may have a greater likelihood of success.

Aware that partial reforms are likely to lead to adaptation without substantial change, critics now often appraise the American adversary process in light of European counterparts. Within the past few years there has been a spate of publications comparing Continental inquisitorial systems with the American criminal process (Goldstein, 1975; Goldstein and Marcus, 1977; Weinreb, 1977; Langbein, 1975; Langbein and Weinreb, 1978). Although these discussions move far beyond the question of plea bargaining, the demise of trials and the rise of plea bargaining has been an important stimulus.

\section{CONCLUSIONS}

The papers presented at the French Lick Conference covered a wide range of topics. Taken together they present a comprehensive portrait of contemporary issues in plea bargaining. Although none supplies definitive answers, they probe the 
questions deeply. Because each paper touches on several themes and all the issues are closely interrelated, it is difficult to order the papers in a neat sequence. Thus the reader should keep in mind that each might reasonably be read as a complement to several others. The first group of articles examines the guilty plea in historical perspective. The second presents comparative analyses of plea bargaining and its alternatives in other legal systems. A third set of papers reports on various efforts to structure or eliminate plea bargaining. Section four focuses on recent research on plea bargaining. The concluding group of papers raises philosophical questions about the desirability and propriety of plea bargaining.

Albert Alschuler, Lawrence Friedman, Mark Haller, John Langbein, and Lynn Mather explore the historical dimensions of plea bargaining, uncovering fresh material. Alschuler, a well-known critic of the practice, has examined the historical decline of the trial in an effort to answer fatalists who contend that "plea bargaining is inevitable" or "has always been with us." Although we can point to an era in which there was little if any plea bargaining, its remoteness raises doubts about its salience for today's reformers. Still, Alschuler usefully elucidates the reasons for the demise of the trial and for changes in the ideology surrounding it. Less expansive in scope, Friedman's paper examines the operation of criminal courts in Alameda County, California, at the turn of the century, illuminating both contemporary practice concerning guilty pleas and its significance for the meaning of a "trial." He finds that courts routinely disposed of several cases in a day, suggesting that trials were very different from the drawn-out affairs of today. He hypothesizes that the decline in trials is attributable to the rise of full-time professionals and the introduction of technology rather than to a greater willingness to lower the standards of justice in order to handle cases more rapidly. Mark Haller extends this line of reasoning, suggesting that in some cities the range of factors open to "negotiation" has actually shrunk over the years. Lynn Mather points to other factors that may explain the rise of plea bargaining, such as changing ideas about punishment and sentencing and expansion in the scope of the substantive criminal law.

John Langbein offers a brief but illuminating comparison between the developments of the inquisitorial systems of Northern Europe and the Anglo-American adversary system. He suggests that historical differences in the conception of the role of prosecutors account for the lack of plea bargaining on 
the Continent and its acceptance in the United States. His argument is original and convincing. It also demonstrates the value of comparative and historical research in a field that is too insular and parochial, and as such should serve as a model for future criminal justice scholarship.

The second group of papers also attempts to enlarge the context within which we examine plea bargaining. Baldwin and McConville describe the process of guilty pleas in England, a jurisdiction that, until recently, denied the existence of plea bargaining, leading many American scholars and practitioners to hold it up as a model for emulation. Their paper is an exercise in demythologizing. The behavior they uncover will seem familiar to Americans who will probably be more surprised by the reaction that the research elicited when it was first reported in England. The study may require reconsideration of the common assumption about the superiority of the English criminal justice system. Felstiner, though not dealing with plea bargaining as such, explains a German procedure that handles large numbers of less serious offenses without tolerating plea bargaining and yet without clogging the courts with contested cases. It offers hope to those critics of plea bargaining who are also concerned about the flood of work that is predicted if the plea practice is truly eliminated. It remains problematic whether such a procedure is adaptable to the American context with its very different "crime problem" and distinct legal tradition.

The next four papers report attempts to restructure, eliminate, or reduce plea bargaining. Judge Sam Callan describes his nearly single-handed effort to eliminate the disparity between the sentences of those who plead guilty and those who are convicted after trial. His solution, devised without benefit of a study commission or a research grant, is deceptively simple, testifying to what one determined official can accomplish even in the fragmented criminal court system. Heinz and Kerstetter report on a well-planned, tightly controlled experiment in Miami. Cases were randomly assigned to either regular court proceedings or a "pretrial settlement conference" called by the judge, to which were invited not only the prosecutor and defense attorney but also the victim and arresting officer. Although the experiment identified few clear benefits, the authors note that the conference was neither disruptive nor coercive, thus allaying earlier apprehensions. Perhaps the real significance of this project was not its detailed finding but the fact 
that it took place at all. It refutes those who claim that it is impossible to experiment and scientifically evaluate innovations in the criminal courts.

Michael Rubenstein and Teresa White examine the impact of the Alaska experiment in abolishing plea bargaining. They emphasize that its purpose was not to eradicate all discretion and negotiation at charging, but to take prosecutors out of the business of guaranteeing sentences or reducing or dismissing charges in order to obtain guilty pleas. Another way of characterizing this effort is to see it as an attempt to restore the sentencing function of judges. Given this limited goal, they conclude that the effort was a success; old practices did not reemerge in some other form at another stage of the process. There were, however, some unanticipated effects which they also describe.

Heumann and Loftin, McDonald, Katz, Hagan and Bernstein, Ryan and Alfini, and I each try to broaden the framework within which to generalize about plea bargaining. ${ }^{1}$ Heumann and Loftin examine the implementation in Detroit of the recent Michigan mandatory minimum sentencing law and how the reduction of discretion at one stage was offset by increased discretion at others. McDonald makes one simple yet important point: because there are a host of opportunities for negotiation in the criminal process it makes little sense for analysis or reform to focus on only one. Katz argues that generalizations about the object and process of plea bargaining have little if any relevance to "white-collar" crimes. Here, prosecutors must create such cases and charges, not respond to them; they must determine whether a highly fragmentary factual account might constitute a crime and whether to undertake further investigation that might lead to filing charges. Hagan and Bernstein offer graphic accounts of how this is done, using extensive interviews with criminal justice officials in United States District Courts. Other types of crime, by contrast, are commonly presented to prosecutors by the police in the form of arrests. Generalizations about plea bargaining derive from the latter category and are not likely to be applicable to white-collar crime. I offer another distinction that has been overlooked. Discussions of plea bargaining often assume that the defendant

1 The articles by Hagan and Bernstein and by Ryan and Alfini were not presented at the conference but were subsequently submitted to the Review and are included here because they make significant contributions to the subject of this special issue. 
has an incentive to take a case to trial in the absence of concessions. But in many lesser offenses this may not be true because trial is too costly an option in light of the lenient sanctions that can be anticipated following conviction. Katz, Hagan and Bernstein, and I identify a significant set of criminal cases-probably a substantial majority-for which the standard model of plea bargaining is at best problematic if not altogether inappropriate. Finally, because all of the above studies either describe individual cases or are generalizations from a small number of instances, Ryan and Alfini offer an important complementary perspective using survey research to determine the frequency with which trial judges participate in plea discussions and the legal, organizational, and social context in which they are more likely to do so.

The remaining papers deal with the propriety of plea bargaining. Thomas Church defends the practice, arguing that far from reducing the power and resources of the accused it increases them. To the extent that this is true, he argues, criticism of plea bargaining based on solicitude for the defendant is unfounded and insubstantial. Conrad Brunk explores the issue of coerciveness at length and offers criteria for determining whether plea bargaining is unduly coercive.

Commenting on several of the conference papers, Jonathan Casper notes with irony that just as practitioners are finally beginning to mount the first serious efforts to abolish plea bargaining, the most recent scholarly commentary appears to have become more favorable to it. This shift, he argues, is not the result of intellectual vascillation, but is based on a more sophisticated understanding of how courts operate.

The defense of plea bargaining by Brunk and Church precipitated two specific reactions. Jonathan Hyman briefly explores the criticisms of plea bargaining in light of what he sees as similarities between the guilty plea process and trial. Kenneth Kipnis, a strong opponent of plea bargaining, vigorously attacks the arguments advanced by Brunk and Church, arguing that any accommodation with that practice destroys a coherent and rational theory of criminal punishment and as such violates a fundamental norm of justice.

Samuel Krislov's concluding remarks summarize the common themes in the papers, identify problems of analysis, and point to areas in need of further exploration. His piece is something of an intellectual road map of the ideas presented in the 
individual papers, and as such can profitably be read at the outset, as an introduction to the symposium, and again at the conclusion as a useful summary and critique. Appended to the articles is an annotated bibliography on plea bargaining prepared by Albert Matheny. Finally this special issue of the Review concludes with eight lengthy reviews of nine recent books that deal with the process of negotiated justice in criminal courts. Taken together, the articles, the bibliography, and the reviews introduce the reader to the "compleat library" on plea bargaining.

\section{REFERENCES}

ALSCHULER, Albert W. (1978) "Sentencing Reform and Prosecutorial Power: A Critique of Recent Proposals for 'Fixed' and 'Presumptive' Sentencing," 126 University of Pennsylvanis Law Review 550.

BLUMBERG, Abraham S. (1967) Criminal Justice. Chicago: Quadrangle Books.

COLE, George F. (1970) "The Decision to Prosecute," 4 Law \& Society Review 331.

EISENBERG, Melvin A. (1976) "Private Ordering through Negotiation: Dispute Settlement and Rule Making," 89 Harvard Law Review 376.

EISENSTEIN, James and Herbert JACOB (1977) Felony Justice. Boston: Little, Brown.

FEELEY, Malcolm M. (1975) "The Effects of Heavy Caseloads." Presented at the Annual Meeting of the American Political Science Association, San Francisco, September 5.

- (1979) The Process is the Punishment. New York: Russell Sage Foundation.

FINKELSTEIN, Michael O. (1975) "A Statistical Analysis of Guilty Plea Practices in Federal Courts," 89 Harvard Law Review 293.

GOLDSTEIN, Abraham S. (1974) "Reflections on Two Models: Inquisitorial Themes in American Criminal Procedure," 26 Stanford Law Review 1009.

GOLDSTEIN, Abraham S. and Marvin MARCUS (1977) "The Myth of Judicial Supervision in Three 'Inquisitorial' Systems: France, Italy, and Germany," 87 Yale Law Journal 240.

HEUMANN, Milton (1975) "A Note on Plea Bargaining and Case Pressure," 9 Law \& Society Review 515.

(1978) Plea Bargaining: The Experiences of Prosecutors, Judges, and Defense Attorneys. Chicago: University of Chicago Press.

LANGBEIN, John H. (1974) "Controlling Prosecutorial Discretion in Germany," 41 University of Chicago Law Review 439.

LANGBEIN, John H. and Lloyd WEINREB (1978) "Continental Criminal Procedure: 'Myth' and Reality," 87 Yale Law Journal 1549.

MATHER, Lynn M. (1974) "Some Determinants of the Method of Case Disposition: Decision-Making by Public Defenders in Los Angeles," $8 \mathrm{Law}$ \& Soci. ety Review 187.

ROSETT, Arthur I. and Donald R. CRESSEY (1976) Justice by Consent: Plea Bargains in the American Courthouse. Philadelphia; Lippincott.

UTZ, Pamela J. (1978) Settling the Facts: Discretion and Negotiation in Criminal Courts. Lexington, Mass.: Lexington Books.

VERA INSTTTUTE OF JUSTICE (1977) Felony Arrests: Their Prosecution and Disposition in New York City's Courts. New York: Vera Institute of Justice.

WEINREB, Lloyd (1977) Denial of Justice: Criminal Process in the United States. New York: Free Press.

WISHINGRAD, Jay (1974) "The Plea Bargain in Historical Perspective," 23 Buffalo Law Review 499. 
HeinOnline -- 13 Law \& Soc'y Rev. 210 1978-1979 